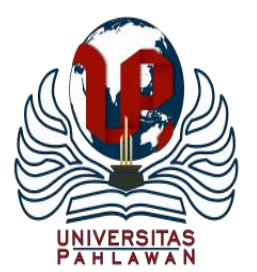

Jurnal Basicedu Volume 5 Nomor 1 Tahun 2021 Halaman 65-76

JURNAL BASICEDU

Research \& Learning in Elementary Education

https://jbasic.org/index.php/basicedu

\title{
Keyakinan Epistemologis dan Belajar-Mengajar Matematika Calon Guru Matematika Sekolah Dasar
}

\author{
Kimura Patar Tamba ${ }^{1}$, Wiputra Cendana ${ }^{2}$, Jesica Pratiwi ${ }^{3}$ \\ Pendidikan Matematika, Universitas Pelita Harapan, Tangerang, Indonesia ${ }^{1}$ \\ Pendidikan Guru Sekolah Dasar, Universitas Pelita Harapan, Tangerang, Indonesia ${ }^{2,3}$ \\ E-mail : Kimura.tamba@uph.edu ${ }^{1}$ Wiputra.cendana@uph.edu² $\underline{\text { Jp80021@ student.uph.edu }}{ }^{3}$
}

\begin{abstract}
Abstrak
Keyakinan epistemologis guru terhadap matematika akan mempengaruhi keyakinannya dalam pembelajaran matematika. Penelitian ini bertujuan untuk mengetahui keyakinan epistemologis, keyakinan belajar-mengajar matematika serta hubungan keduanya pada calon guru matematika sekolah dasar. Kami menggunakan metode penelitian kuantitatif dengan menggunakan survei, yang dilakukan kepada 71 orang mahasiswa calon guru sekolah dasar. Hasil penelitian dipaparkan menjadi dua bagian. Hasil pada bagian pertama yaitu deskripsi keyakinan epistemologis akan matematika dan keyakinan akan belajar- mengajar matematika dari calon guru sekolah dasar, menunjukkan bahwa calon guru sekolah dasar lebih cenderung menyakinan matematika adalah pengetahuan statis. Hasil bagian kedua yaitu analisis korelasi antar keyakinan epistemologis akan matematika dengan keyakinan akan belajar-mengajar matematika, menunjukkan bahwa calon guru sekolah dasar cenderung memegang kedua keyakinan epistemologi statis dan dinamis akan matematika. Penelitian ini memberikan implikasi praktis dalam pendidikan, khususnya pendidikan guru sekolah dasar. Temuan ini mengimplikasikan bahwa untuk mengubah praktik belajar-mengajar matematika, harus dimulai dengan menguji ataupun mengubah keyakinan calon guru sekolah dasar mengenai epistemologi matematika.
\end{abstract}

Kata kunci : epistemologis, belajar-mengajar, calon guru sekolah dasar

\section{Abstract}

The teacher's epistemological belief in mathematics will affect his belief in mathematics learning. This study aims to determine epistemological beliefs, beliefs in teaching and learning mathematics and the relationship between the two of prospective elementary school mathematics teachers. We used a quantitative research method using a survey, which was conducted on 71 prospective elementary school teachers. The results of the research are presented in two parts. The results in the first section, namely a description of the epistemological beliefs of mathematics and the belief in teaching and learning of mathematics from prospective elementary school teachers, indicate that prospective elementary school teachers are more likely to believe that mathematics is static knowledge. The results of the second section, namely the correlation analysis between epistemological beliefs in mathematics with beliefs in mathematics teaching and learning, show that prospective elementary school teachers tend to hold both static and dynamic epistemological beliefs in mathematics. This research has practical implications for education, particularly in elementary school teacher education. These findings imply that in order to change the practice of teaching and learning mathematics, it must begin by testing or changing the beliefs of prospective elementary school teachers about the epistemology of mathematics.

Keywords: epistemological, teaching-learning, prospective elementary school teachers

Copyright (c) 2021 Kimura Patar Tamba, Wiputra Cendana, Jesica Pratiwi

$\triangle$ Corresponding author

Address : Gedung B-Lantai 6 Jl. M.H Thamrin Boulevard Tangerang, 15811 Banten

ISSN 2580-3735 (Media Cetak)

ISSN 2580-1147 (Media Online)

Email : Wiputra.cendana@uph.edu

Phone : 085739919999

DOI : https://doi.org/10.31004/basicedu.v5i1.573 


\section{PENDAHULUAN}

Keyakinan mengenai pengetahuan matematika, sering disebut keyakinan epistemologis, merupakan bagian krusial dalam kompetensi profesional guru matematika. Hal ini dikarenakan keyakinan akan matematika akan menentukan bagaimana matematika dinyatakan dalam situasi kelas (Beswick, 2012; Cross, 2009; Ernest, 1989; Felbrich et al., 2012). Dengan kata lain, keyakinan epistemologis guru terhadap matematika akan mempengaruhi keyakinannya dalam pembelajaran matematika.

Oleh karena itu penelitian mengenai keyakinan epistemologis, keyakinan akan pembelajaran matematika dan hubungan keduanya masih menjadi bidang yang sangat dipertimbangkan. Berbagai penelitian mengenai hal ini telah banyak dilakukan. Meski tidak selalu linear, hasil penelitian menunjukkan bahwa terdapat hubungan antara keyakinan epistemologis akan matematika dan keyakinan akan belajarmengajar matematika. Contohnya, studi dari Cross (2009) yang menunjukkan guru yang memiliki keyakinan bahwa matematika adalah penjumlahan, pengurangan, operasi dan kumpulan formula akan cenderung melihat memorization \& practice adalah yang paling penting dalam pembelajaran matematika. Untuk itu pembelajaran yang desainnya lebih mengarah pada pemaparan pada formula dan penggunaan formula. Di lain pihak, guru yang memiliki kepercayaan bahwa matematika adalah penyelesaian masalah yang kompleks akan mengkonstruksi pembelajaran yang mendorong siswa belajar berpikir kritis dan logis, menjadi pembelajar mandiri.
Di Indonesia, penelitian mengenai keyakinan epistemologis belum dilakukan cukup luas (Yoppy Wahyu Purnomo et al., 2016). Meskipun demikian, keyakinan epistemologis dan belajar mengajar keyakinan akan matematika sudah mulai mendapat perhatian dari peneliti di Indonesia (Purnomo, 2017; Purnomo et al., 2018; Purnomo et al., 2016; Siswono et al., 2016, 2017; Yuli et al., 2019). Penelitian melaporkan bahwa keyakinan guru akan pengetahuan memiliki hubungan yang kuat dengan keyakinannya akan pemecahan masalah (Siswono et al., 2016, 2017). Namun beberapa penelitian lain mengungkapkan keyakinan guru akan praktek pembelajaran (Purnomo et al., 2016; Siswono et al., 2016, 2017).

Berbagai penelitian di atas, khususnya penelitian di Indonesia, hanya penelitian Purnomo et al. (2016) yang telah mengeksplorasi keyakinan epistemologis pada calon guru matematika sekolah dasar. Penelitian tersebut menunjukkan bahwa bahwa praktik pembelajaran tidak serta merta mencerminkan keyakinan yang dianut. Di sisi lain, keyakinan tentang nature matematika berpengaruh lebih dominan daripada keyakinan lain terhadap praktik pembelajaran.

Penelitian mengenai keyakinan epistemologis calon guru matematika sekolah dasar di Indonesia bersifat kualitatif, yaitu studi kasus dari satu calon guru matematika sekolah dasar. Bahkan secara global, sebagian besar penelitian mengenai topic ini diberbagai belahan dunia memang cenderung dilakukan secara kualitatif (Liljedahl et al., 2019; Stohlmann et al., 2014). Kekhususan ini membatasi pemahaman mengenai gambaran keyakinan epistemologis 
calon guru matematika sekolah dasar dan hubungan yang kompleks di antara keyakinan epistemologis dan keyakinan belajar-mengajar matematika. Untuk itu, perlu dikembang model yang lebih canggih dalam menggambarkan keyakinan epistemologis matematika, keyakinan akan belajar-mengajar matematika dan hubungan antar keduanya.

Penelitian ini bertujuan untuk mengetahui keyakinan epistemologis, keyakinan belajarmengajar matematika serta hubungan keduanya pada calon guru matematika sekolah dasar. Dengan demikian secara detail, penelitian ini akan melakukan investigasi dan analisis atas tiga hal, yaitu (1) keyakinan epistemologis calon guru matematika sekolah dasar; (2) keyakinan belajarmengajar matematika calon guru matematika sekolah dasar; (3) hubungan antara keduanya.

Jadi pertanyaan penelitian yang menuntun penelitian ini meliputi: (1) bagaimana keyakinan epistemologis akan matematika dari calon guru matematika sekolah dasar; (2) bagaimana keyakinan belajar-mengajar matematika calon guru matematika sekolah dasar; (3) bagaimana hubungan karateristik keyakinan epistemologis akan matematika dengan keyakinan belajarmengajar matematika dari calon guru matematika sekolah dasar? Temuan dalam penelitian ini akan menyediakan bukti empiris kuantitatif mengenai keyakinan epistemologis akan matematika, keyakinan (belief) akan pembelajaran matematika dan relasi keduanya pada calon guru matematika sekolah dasar pada konteks Indonesia.

Secara historis keyakinan epistemologis pertama kali diselidiki oleh William Perry (1968), yang menguji keyakinan mahasiswa atas nature dan sumber pengetahuan (Duell \& Schommer, 2001). Kemudian topik ini pun mulai banyak dibahas dan diteliti dalam pendidikan matematika. Keyakinan epistemologis matematika didefenisikan sebagai keyakinan akan natur matematika dan perolehan pengetahuan matematika (Op't Eynde, De Corte \& Verschaffel, 2002; Baumert and Kunter 2006; Ernest 1989; Goldin et al. 2009; Op't Eynde et al. 2002; Philipp 2007; Sullivan and Wood 2008; Felbrich, Kaiser \& Schmotz, 2012; Liu, 2010).

Dalam konteks pendidikan, beberapa skema kategorisasi keyakinan epistemologis guru dan calon guru matematika telah dikembangkan. Pertama, Ernest (1989) membagi keyakinan epistemologis menjadi tiga yaitu Platonis view, instrumentalis view dan problem-solving view. Instrumentalis melihat matematika sebagai akumlasi fakta, keterampilan dan aturan yang tidak saling terkait. Sementara Platonis berpandangan matematika sebagai entitas yang statis, pengetahuan yang sangat terstruktur, saling terkait dan harus ditemukan. Pandangan problem-solving memahami matematika sebagai penemuan manusia yang sifatnya dinamis dan relatif, serta menekankan pada proses bermatematika.

Lebih detail, Grigutsch et al. (1998) dan Blömeke et al. (2008) membagi menjadi empat kategori yaitu: (1) perspektif terkait skema di mana matematika dipahami sebagai kumpulan aturan dan rumus (pandangan ini sejalan dengan perspektif instrumentalis Ernest); (2) perspektif formalis tentang matematika yang menekankan sifat matematika yang tepat, formal, dan logis 
(sesuai dengan perspektif Platonis Ernest); (3) perspektif terkait proses di mana matematika dikandung sebagai ilmu yang ditandai oleh pemecahan masalah (perspektif ini menyerupai pandangan pemecahan masalah Ernest); dan (4) perspektif aplikasi tentang matematika, dimana matematika terutama dianggap relevan untuk masyarakat dan kehidupan.

Namun secara empiris, To"rner and Grigutsch (1994; also Grigutsch et al. 1998) dan Felbrich et al. (2012) menunjukkan bahwa pembagian di atas (membagi menjadi tiga atau empat kategori) dapat dikelompokkan dalam dua perspektif menyeluruh tentang matematika. The Formalism-related dan The Scheme-related view menggolongkan matematika sebagai ilmu statis, sementara The Process-related and The Application-related mengelompokkan matematika sebagai a dynamic process.

Berbagai kategorisasi di atas berakar pada pandangan akan nature dan perolehan matematika itu sendiri. Dalam hal ini Ernest (2014) mengelompokkan dalam dua views akan matematika yaitu absolutisme [Platoisme; disebut juga sebagai realis oleh Bolden \& Newton, (2008); disebut statis oleh Felbrich et al. (2012)] dan fallibilisme [disebut juga sebagai relativis oleh Bolden \& Newton, (2008); disebut dinamis oleh Felbrich et al. (2012)]. Hal yang sama diungkapkan oleh Op't Eynde, De Corte \& Verschaffel (2002) yang melihat setiap skema kategorisasi keyakinan epistemologis guru ini selalu dapat dikelompokkan kembali dan berakar pada padangan absolutisme dan fallibilisme akan matematika (Lerman, 1983). Dimana absolutisme mencakup Platonis view dan instrumentalis view dari Ernest (2014), perspektif terkait skema dan perspektif formalis dari Grigutsch et al. (1998) dan Blömeke et al. (2008). Sementara, fallibilisme mencakup problem-solving view dari Ernest (2014), perspektif terkait proses dan perspektif aplikasi dari Grigutsch et al. (1998) dan Blömeke et al. (2008).

Oleh karena itu dalam penelitian ini keyakinan epistemology of mathematics dibagi menjadi dua yaitu statis (absolutisme) dan dinamis (fallibilisme). Kerangka ini sesuai dengan kerangka yang digunakan oleh penelitian TEDS-M (Teacher Education and Development Study in Mathematics). Penelitian TEDS-M melakukan penelitian terhadap keyakinan epistemologis akan matematika dengan menggunakan kategori statis dan dinamis (Döhrmann et al., 2012; Tatto et al., 2008).

Keyakinan guru mengenai belajar dan mengajar matematika merujuk pada pandangan guru tentang pengajaran matematika yang mereka sukai dan pandangan bagaimana matematika dipelajarai (Yuli et al., 2019). Keyakinan ini mencakup konsepsi mengenai aktivitas belajar dan mengajar di kelas yang ideal, peran guru, peran siswa, perilaku dan kegiatan mental yang terlibat dalam pembelajaran matematika (Chan dan Elliott 2004; Ernest 1989; Thompson 1992). Sama seperti keyakinan epistemologis, terdapat variasi dalam kategorisasi keyakinan guru mengenai belajar dan mengajar matematika. Dalam hal pengajaran matematika keyakinan guru dapat dibagi menjadi tiga pandangan yang berbeda yaitu berfokus pada pembelajar (learner-focused), berfokus pada 
konten dengan penekanan pada performa (contentfocused with an emphasis on performance), berfokus pada konten dengan penekanan pada pemahaman (content-focused with an emphasis on understanding) (Beswick, 2012; Van Zoest et al., 1994). Peneliti lain membuat kategori keyakinan akan pengajaran matematika menjadi pengajaran berpusat pada guru ('teacher-centered' teaching keyakinan) and pengajaran berpusat pada siswa ('student-centered teaching keyakinan) (Beswick, 2012). Kategori pengajaran berpusat pada guru sejajar dengan keyakinan content-focused sementara berpusat pada siswa bersesuaian dengan learner-focus.

Pembagian ini sesuai dengan kerangka penelitian TEDS-M, keyakinan guru akan belajar dan mengajar matematika dibedakan menjadi dua yaitu (1) pandangan transmisi pengetahuan (atau "tradisional"), dimana pengajaran matematika dipandang sebagai proses pengetahuan transmisi dan siswa menerima pengetahuan dari guru secara pasif, dan (2) pandangan konstruktivis, dimana pengajaran matematika dilihat sebagai memfasilitasi konstruksi pengetahuan siswa (Döhrmann et al., 2012; Tatto et al., 2008). Pandangan transmisi pengetahuan sejajar dengan pengajaran berpusat pada guru dan keyakinan berfokus konten (belief content-focused), sementara pandangan kontruktivis bersesuaian dengan pengajaran berpusat pada siswa dan keyakinan berfokus pada siswa (belief learnerfocus).

Penelitian ini akan menggunakan kerangka penelitian TEDS-M. Hal ini dipilih karena kategori belief akan pengajaran matematika telah diintegrasikan dengan keyakinan akan belajar matematika. Pengajaran matematika dan belajar matematika adalah dua hal yang tidak dapat dipisahkan, membicarakan yang pertama tidak mungkin tanpa yang kedua.

\section{METODE}

Penelitian menggunakan metode penelitian kuantitatif dengan menggunakan survey. Metode ini dipilih karena cocok dengan penelitian yang bertujuan untuk mendeskripsikan situasi yang ada pada masalah lalu atau saat ini (Cohen et al., 2018).

Partisipan dalam penelitian ini adalah 71 orang calon guru sekolah dasar (10 laki-laki dan 61 perempuan). Semua partisipan telah menyelesaikan semua mata kuliah mengenai pedagogi umum, konten matematika (seperti matematika dasar, geometri, matematika sekolah dasar) dan sedang mengambil mata kuliah mengenai pengajaran matematika. Partisipan ini terbagi menjadi dua kelompok yaitu kelas dengan pengantar berbahasa Indonesia dan kelas dengan pengantar dua bahasa (bahasa Indonesia dan Inggris).

Data yang dikumpulkan dalam penelitian ini adalah data kuantitatif mengenai keyakinan epistemologis akan matematika dan keyakinan akan belajar dan mengajar matematika dari calon guru sekolah dasar. Pengumpulan data dilakukan dengan menggunakan kuisioner. Penelitian ini menggunakan kuisioner dari TEDS-M (Döhrmann et al., 2012; Tatto et al., 2008) yang menginvestigasi keyakinan calon guru matematika 
mengenai nature matematika dan, belajar dan mengajar matematika.

Pada kuisioner, terdapat total 12 item mengenai keyakinan akan hakikat matematika. Bagian ini terbagi menjadi dua dimensi, yaitu matematika sebagai ilmu yang statis (6 item, dengan contoh item: "Matematika adalah kumpulan aturan dan prosedur yang mengatur bagaimana memecahkan suatu masalah") dan matematika sebagai ilmu yang dinamis (6 item, dengan contoh item: "Konsep (rumus, teorema, dll) dalam matematika adalah hasil kreativitas dan ide-ide baru (tidak benar-benar sama dari jaman ke jaman"). Kuisioner dapat dilihat di Tatto et al. (2008).

Pernyataan mengenai keyakinan akan belajar dan mengajar matematika juga mencakup dua dimensi yaitu pandangan transmisi pengetahuan (atau "tradisional") dan pandangan konstruktivis. Masing-masing dimensi diwakili oleh 6 item pernyataan. Contoh pernyataan dimensi keyakinan tradisional adalah "cara terbaik belajar matematika adalah menghafal semua rumus." Contoh pernyataan dimensi keyakinan konstruktivis adalah "guru harus mengizinkan anak untuk menemukan cara mereka sendiri untuk memecahkan masalah matematika." Kuisioner ini menggunakan skala asli dari kuisioner TEDS-M yaitu Likert enam poin $(1$ = "sangat tidak setuju" dan 5 = "sangat setuju").

Untuk kuisioner keyakinan epistemologi semua butir pernyataan valid, dengan nilai korelasi Pearsonnya berada pada rentang 0,313 sampai 0,742 dan signifikan untuk $\alpha=0,05$. Nilai Cronbach's Alpha sebesar 0,786 (lebih besar dari
0,5) menunjukkan bahwa kuisioner memiliki reliabilitas yang tinggi. Dengan demikian, kuisioner tersebut dapat digunakan pada konteks penelitian ini. Sementara untuk kuisioner keyakinan belajar-mengajar matematika tidak semua butir pernyataan valid, ada tiga pernyataan tidak signifikan untuk $\alpha=0,05$ yaitu pernyataan ketujuh (keyakinan berpusat pada konten), pernyataan kesembilan dan pernyataan kesebelas (keyakinan berpusat pada siswa). Untuk itu ketiga pernyataan ini tidak digunakan. Setelah membuang ketiga pernyataan tersebut diperoleh nilai korelasi pearsonnya berada pada rentang 0,239 sampai 0,647. Nilai Cronbach's Alpha untuk kuisioner keyakinan belajar-mengajar sebesar 0,664 (lebih besar dari 0,5). Artinya kuisioner ini memiliki reliabilitas tinggi. Dengan demikian, kuisioner tersebut dapat digunakan pada konteks penelitian ini.

Analisis data akan dilakukan secara kuantitatif baik secara deskriptif maupun secara inferensial (korelasi). Untuk menjawab pertanyaan penelitian pertama dan kedua dilakukan analisis data secara deskriptif yaitu dengan menghitung nilai mean dan standar deviasi (Döhrmann et al., 2012; Tatto et al., 2008; Yang et al., 2020). Untuk menjawab pertanyaan pertama, analisis ini dilakukan dengan menghitung mean dan standar devisi untuk masing-masing dimensi keyakinan epistemologis akan matematika. Begitu juga untuk melihat karateristik keyakinan akan belajar dan mengajar matematika dilakukan analisis deskriptif dengan menghitung mean dan standar deviasi untuk masing-masing dimensi ("tradisional" dan "konstruktivis"). Dimensi yang memiliki nilai 
mean yang lebih tinggi dibanding dimensi lain menunjukkan bahwa calon guru sekolah dasar cenderung meyakini dimensi tersebut.

Untuk menjawab pertanyaan penelitian kedua maka dilakukan analisis korelasi dengan Pearson Moment Product antar dimensi. Analisis regresi juga digunakan untuk menguji kekuatan regresi dari hubungan antar dimensi ini. Analisis dilakukan dengan menggunakan batuan software SPSS 20.0.

\section{HASIL DAN PEMBAHASAN}

Hasil penelitian akan dipaparkan dalam dua bagian yaitu bagian pertama mengenai deskripsi keyakinan epistemologis akan matematika dan keyakinan akan belajar dan mengajar matematika dari calon guru sekolah dasar. Bagian pertama akan menjawab pertanyaan penelitian pertama dan kedua. Bagian kedua merupakan analisis korelasi antar keyakinan epistemologis akan matematika dengan keyakinan akan belajar dan mengajar matematika. Bagian kedua ini akan menjawab pertanyaan penelitian ketiga.

\section{Deskripsi keyakinan epistemologis dan keyakinan belajar-mengajar matematika}

Hasil analaisis data deskriptif mengenai keyakinan epistemologis akan matematika dan keyakinan akan belajar-mengajar matematika terlihat pada Tabel 1. Dalam hal keyakinan epistemologis, dari tabel tersebut terlihat bahwa skor rata-rata dari keyakinan statis lebih tinggi dibanding keyakinan dinamis. Ini menunjukkan bahwa calon guru sekolah dasar lebih cenderung menyakinan matematika adalah pengetahuan statis.
Dengan kata lain, keyakinan statis calon guru sekolah dasar akan matematika lebih tinggi dibanding keyakinan dinamis. Namun rata-rata skor dari keyakinan statis lebih tinggi dari 4 menunjukkan bahwa calon guru juga memiliki keyakinan yang tinggi bahwa matematika adalah pengetahuan yang dinamis. Ini menunjukkan bahwa calon guru sekolah dasar cenderung memegang keyakinan epistemologis campuran (antar dinamis dan statis).

Tabel 1. Gambar Deskriptif dari Hasil Keyakinan Epistemologis dan Keyakinan BelajarMengajar Matematika Calon Guru Sekolah Dasar

\begin{tabular}{lcccc}
\hline & Min. & Max. & Mean & Std.Dev. \\
\hline Keyakinan Statis & 3.17 & 6.00 & 5.21 & 0.51 \\
\hline $\begin{array}{l}\text { Keyakinan } \\
\text { Dinamis }\end{array}$ & 3.00 & 5.83 & 4.62 & 0.67 \\
\hline $\begin{array}{l}\text { Keyakinan } \\
\text { Pembelajaran } \\
\text { Tradisional }\end{array}$ & 1.71 & 5.00 & 3.33 & 0.66 \\
$\begin{array}{l}\text { Keyakinan } \\
\text { Pembelajaran } \\
\text { Konstruktivis }\end{array}$ & 3.00 & 6.00 & 4.77 & 0.63 \\
\hline
\end{tabular}

Sementara mengenai keyakinan akan belajar-mengajar matematika, nilai mean keyakinan pembelajaran kontruktivis $(4,77)$ lebih tinggi dibanding keyakinan pembelajaran tradisional (3,33). Artinya calon guru sekolah dasar lebih condong memegang keyakin pembelajaran konstruktivisme dibanding pembelajaran tradisional. Namun, sama halnya dengan keyakinan epistemologis akan matematika, kelihatannya calon guru sekolah dasar cenderung memegang kedua keyakinan ini (tradisional maupun konstruktivis). Ini ditunjukkan dari nilai mean keyakinan tradisional lebih tinggi dari 3. 


\section{Korelasi antar Keyakinan}

Hasil analisis korelasi antar keyakinan epistemologis akan matematika dengan keyakinan akan belajar-mengajar matematika ditampilkan pada tabel 2. Sebagaimana ditunjukkan pada Tabel 2, terdapat korelasi positif dan signifikan antara keyakinan epistemologi statis akan matematika dengan keyakinan dinamis akan matematika pada calon guru sekolah dasar. Hal ini menunjukkan bahwa calon guru sekolah dasar cenderung memegang kedua keyakinan ini. Hal ini sesuai dengan analisis deskriptif sebelumnya, bahwa meski mean dari keyakinan statis lebih tinggi dari keyakinan dinamis, namun mean dari keyakinan dinamis lebih besar dari 4. Dalam hal hubungannya dengan keyakinan akan belajarmengajar matematika, ditemukan keyakinan epistemologi statis akan matematika berkorelasi positif dengan keyakinan pembelajaran konstruktivis tetapi tidak dengan keyakinan pembelajaran tradisional.

Selain itu, ada korelasi positif antar keyakinan epistemologi dinamis akan matematika calon guru dengan keyakinannya pada pembelajaran tradisional. Namun, keyakinan dinamis ini juga berkorelasi positif dengan keyakinan pembelajaran konstruktivis. Artinya, calon guru sekolah dasar yang memiliki keyakinan dinamis cenderung memiliki keyakinan campuran akan belajar-mengajar matematika (memegang kedua keyakinan, baik tradisional maupun konstruktivis).
Tabel 2. Matrik Korelasi Bivariat Antar Keyakinan

\begin{tabular}{lcccc}
\hline & KS & KD & KT & KK \\
\hline $\begin{array}{l}\text { Keyakinan } \\
\text { Statis (KS) }\end{array}$ & 1 & $0,449^{* *}$ & 0,147 & $0,366^{* *}$ \\
\hline $\begin{array}{l}\text { Keyakinan } \\
\text { Dinamis } \\
(\text { KD) }\end{array}$ & 1 & $0,303^{*}$ & $0,354^{* *}$ \\
\hline $\begin{array}{l}\text { Keyakinan } \\
\text { Tradisional } \\
(\text { KT) }\end{array}$ & & & \\
\hline $\begin{array}{l}\text { Keyakinan } \\
\text { Konstruktivis } \\
(\text { KK) }\end{array}$ & & 1 & 0,118 \\
**. Korelasi signifikan pada level 0,$01 ; *$. Korelasi \\
signifikan pada level 0,05
\end{tabular}

Penelitian menggunakan kerangka dan instrument dari TEDS-M untuk memaparkan keyakinan epistemologi akan matematika, keyakinan belajar-mengajar matematika serta korelasi keduanya pada 71 calon guru sekolah dasar. Sebagaimana diungkapkan di atas calon guru sekolah dasar cenderung memagang keyakinan epistemologi statis akan matematika. Hal ini konsisten dengan penelitian sebelumnya mengenai keyakinan calon guru matematika sekolah sekolah dasar. Penelitian studi kasus Purnomo et al., (2016) pada satu calon guru matematika sekolah dasar menunjukkan bahwa keyakinan statis akan natur matematika cenderung dipegang.

Meskipun begitu, calon guru matematika sekolah dasar juga cenderung setuju dengan keyakinan epistemologi dinamis akan matematika. Ini disimpulkan karena meskipun mean keyakinan statis lebih tinggi dari keyakinan dinamis, tapi mean keyakinan dinamis yang tinggi (di atas 3) menunjukkan bahwa mereka juga setuju pada keyakinan tersebut. Temuan ini menunjukkan bahwa keyakinan calon guru matematika sekolah 
dasar cenderung merupakan campuran dari keduanya (statis dan dinamis) dibanding benarbenar memegang salah satu dan menolak yang lain. Temuan ini sesuai dengan penelitian terdahulu yang menemukan bahwa calon guru cenderung memiliki keyakinan campuran (Beswick, 2012; Felbrich et al., 2012; Tang \& Hsieh, 2014; Yang et al., 2020). Hal ini memang terlihat bertentangan dimana calon guru matematika sekolah dasar setuju bahwa matematika adalah ilmu yang statis (statis, platonisme, absolutism) dan disaat bersamaan setuju bahwa matematika sebagai ilmu yang dinamis, hasil kreativitas dan ide-ide baru (dinamis, fallibilisme). Hal ini juga sesuai dengan penelitian dari Xenofontos (2018) yang mengungkapkan bahwa guru dengan keyakinan yang secara eksplisit falibilistik (dinamis) juga dapat mempertahankan keyakinan Platonis (statis). Ini terlihat dari rata-rata keyakinan dinamis yang tinggi. Oleh karena itu, kesimpulan penulis adalah calon guru matematika sekolah dasar cenderung memiliki keyakinan campuran. Kesimpulan ini diambil penulis dengan berpedoman pada pandangan bahwa sistem kepercayaan tidak selalu terstruktur secara logis. Oleh karena itu mungkin bagi seorang guru untuk memegang keyakinan yang tidak sesuai atau tidak konsisten (Op't Eynde et al., 2002; Xenofontos, 2018).

Dalam hal keyakinan akan belajar-mengajar matematika, calon guru matematika sekolah dasar lebih cenderung memegang keyakinan konstruktivis. Meskipun begitu, calon guru matematika sekolah dasar juga memiliki keyakinan yang tinggi pada belajar-mengajar tradisional. Hal ini ditunjukkan oleh nilai rata-rata keyakinan tradisional lebih besar dari 3. Dengan demikian, sama halnya dengan keyakinan epistemologis, calon guru matematika sekolah dasar cenderung memegang keyakinan campuran akan belajarmengajar matematika. Temuan ini konsisten dengan penelitian terdahulu yang memaparkan bahwa calon guru dan guru cenderung tidak konsisten atau memegang dua keyakian pada saat yang bersamaan (Purnomo, 2017; Xenofontos, 2018; Yang et al., 2020).

Temuan lain adalah terdapat hubungan positif dan signifikan antara keyakinan epistemologis (statis maupun dinamis) dengan keyakinan konstruktivis dan antara keyakinan epistemologis dinamis dengan keyakinan tradisional. Temuan ini menunjukkan bahwa terdapat korelasi antara keyakinan epistemologis akan matematika dengan keyakinan belajarmengajar matematika. Hal ini konsisten dengan temuan pada penelitian sebelumnya (Beswick, 2012; Purnomo et al., 2016; Xenofontos, 2018; Yang et al., 2020). Namun yang menarik adalah malah tidak terdapat hubungan antara keyakinan epistemologis dinamis dengan keyakinan belajarmengajar tradisional. Hal ini menunjukkan terdapat hubungan kompleks antar keyakinan epistemologis matematika dengan keyakinan belajar-mengajar matematika (Purnomo et al., 2016; Xenofontos, 2018; Yang et al., 2020).

Penelitian ini memberikan konstribusi pada khasanah pengetahuan dan penelitian mengenai keyakinan epistemologis akan matematika dan keyakinan belajar-mengajar matematika dalam dua hal. Pertama, meskipun temuan konsisten dengan 
penelitian Purnomo et al. (2016), penelitian ini memberikan gambaran yang lebih luas dengan melibatkan partisipan lebih banyak dan memperluas secara metodologis (studi kuantitatif). Kedua, dalam konteks pendidikan di Indonesia, penelitian ini memberikan kontribusi bahwa keyakinan epistemologis akan matematika dan keyakinan belajar-mengajar matematika yang dipegang calon guru matematika sekolah dasar tidak selalu eksplisit pada satu keyakinan tertentu.

Meskipun demikian, penelitian ini memiliki keterbatasan. Temuan di atas harus dilihat dalam beberapa keterbatasan berikut. Pertama, instrument (kuisioner) yang digunakan adalah instrument yang dikembangkan oleh TEDS-M tanpa melakukan modifikasi, selain terjemahan pada bahasa Indonesia. Oleh karena itu, ada kemungkinan konteks khusus yang tidak dapat diungkapkan dalam penelitian ini. Penelitian berikutnya perlu mempertimbangkan pembuatan instrument yang berbasis konteks Indonesia. Hal ini dimungkinkan karena fakta, ada banyak bentuk instrument yang digunakan dalam berbagai konteks yang berbeda (misalnya, Beswick, 2012; Felbrich et al., 2012; Yoppy Wahyu Purnomo, 2017; Tatto et al., 2008; Ünlü \& Sarpkaya, 2013; Xenofontos, 2018; Yuli et al., 2019).

\section{SIMPULAN}

Sebagaimana diungkapkan diatas, temuan dari penelitian ini menunjukkan bahwa calon guru matematika sekolah dasar cenderung memegang keyakinan statis akan epistemologi matematika. Meskipun demikian, calon guru matematika sekolah dasar juga memiliki keyakinan yang tinggi bahwa epistemologi matematika dinamis. Oleh karena itu, dapat dikatakan bahwa calon guru matematika sekolah dasar cenderung memiliki keyakinan campuran (statis dan dinamis), dengan lebih condong pada keyakinan statis akan epistemologi matematika. Demikian halnya dengan keyakinan belajar-mengajar matematika, calon guru matematika sekolah dasar cenderung memiliki keyakinan campuran (tradisional dan konstruktivis), dengan lebih condong pada keyakinan konstruktivis. Temuan penelitian ini juga menunjukkan bahwa terdapat hubungan antar keyakinan epistemologi matematika dengan keyakinan belajar-mengajar matematika. Calon guru yang memiliki keyakinan dinamis akan epistemologi matematika berkorelasi dengan kedua keyakinan belajar-mengajar matematika. Sementara keyakinan statis akan epistemologi matematika berkorelasi dengan keyakinan belajarmengajar matematika konstruktivis, tetapi tradisional tidak.

Temuan penelitian ini memberikan implikasi praktis dalam pendidikan, khususnya pendidikan guru sekolah dasar. Temuan ini mengimplikasikan bahwa untuk mengubah praktik belajar-mengajar matematika, harus dimulai dengan menguji ataupun mengubah keyakinan calon guru sekolah dasar mengenai epistemologi matematika.

\section{DAFTAR PUSTAKA}

Beswick, K. (2012). Teachers' beliefs about school mathematics and mathematicians' mathematics and their relationship to practice. Educational Studies in Mathematics, $\quad$ 79(1), 127-147. 
https://doi.org/10.1007/s10649-011-9333-2

Cohen, L., Manion, L., \& Morrison, K. (2018). Research Methods in Education (8th ed.). Routledge.

Cross, D. I. (2009). Alignment, cohesion, and change: Examining mathematics teachers' belief structures and their influence on instructional practices. Journal of Mathematics Teacher Education, 12(5), 325346. https://doi.org/10.1007/s10857-0099120-5

Döhrmann, M., Kaiser, G., \& Blömeke, S. (2012). The conceptualisation of mathematics competencies in the international teacher education study TEDS-M. ZDM International Journal on Mathematics Education, 44(3), 325-340. https://doi.org/10.1007/s11858-012-0432-z

Ernest, P. (1989). The impact of beliefs on the teaching of mathematics. Mathematics Teaching: The State of the Art, 1980, 249254.

Felbrich, A., Kaiser, G., \& Schmotz, C. (2012). The cultural dimension of beliefs: an investigation of future primary teachers' epistemological beliefs concerning the nature of mathematics in 15 countries. ZDM International Journal on Mathematics Education, 44(3), 355-366. https://doi.org/10.1007/s11858-012-0418-x

Liljedahl, P., Rösken, B., \& Rolka, K. (2019). Changes to preservice elementary teachers, beliefs about mathematics and the teaching and learning of mathematics: How and why?

https://doi.org/10.1556/2059.03.2019.09

Op't Eynde, P., De Corte, E., \& Verschaffel, L. (2002). Framing students' mathematicsrelated beliefs. In G. Leder, E. Pehkonen, \& G. T€orner (Eds.), Beliefs: A Hidden Variable in Mathematics Education? (pp. 13-37). Kluwer Academic Publishers. https://doi.org/10.1007/0-306-47958-3_10

Purnomo, Y. W. (2017). The Complex Relationship between Teachers, Mathematics-related Beliefs and their Practices in Mathematics Class The complex Relationship between Teachers
Mathematics-related Beliefs and Their Practices in Mathematics Class. April. https://doi.org/10.15804/tner.2017.47.1.16

Purnomo, Y. W., Aziz, T. A., Pramudiani, P., Darwis, S., \& Suryadi, D. (2018). Potential characteristics that relate to teachers mathematics-related beliefs. Journal of Physics: Conference Series, 948(1), 0-8. https://doi.org/10.1088/17426596/948/1/012062

Purnomo, Yoppy Wahyu, Suryadi, D., \& Darwis, S. (2016). Examining pre-service elementary school teacher beliefs and instructional practices in mathematics class. 8(June), 629 642.

Siswono, T. Y. E., Kohar, A. W., \& Hartono, S. (2017). Secondary Teachers' Mathematicsrelated Beliefs and Knowledge about Mathematical Problem-solving. Journal of Physics: Conference Series, 1, 1-7. https://doi.org/10.1088/17426596/755/1/011001

Siswono, T. Y. E., Kohar, A. W., Kurniasari, I., \& Astuti, Y. P. (2016). An Investigation of Secondary Teachers' Understanding and Belief on Mathematical Problem Solving. Journal of Physics: Conference Series, 693(1), 0-19. https://doi.org/10.1088/17426596/693/1/012015

Stohlmann, M., Cramer, K., \& Maiorca, C. (2014). Changing Pre-service Elementary Teachers ' Beliefs about Mathematical Knowledge.

Tang, S. J., \& Hsieh, F. J. (2014). The cultural notion of teacher education: Future lower secondary teachers' beliefs on the nature of mathematics, the learning of mathematics and mathematics achievement. In S. Blömeke, F. J. Hsieh, G. Kaiser, \& W. Schmidt (Eds.), The Conceptualisation of Mathematics Competencies in the International Teacher Education Study TEDS-M (pp. 231-253). Springer. https://doi.org/10.1007/978-94-007-64378_20

Tatto, M. T., Schwille, J., Senk, S. L., Ingvarson, L., Peck, R., \& Rowley, G. (2008). Teacher Education and Development Study in Mathematics (TEDS-M). 
Ünlü, M., \& Sarpkaya, G. (2013). Beliefs ' of Preservice Elementary Mathematics Teachers, and Mathematics Department Students about Mathematics. 93(1997), 742-746. https://doi.org/10.1016/j.sbspro.2013.09.273

Van Zoest, L. R., Jones, G. A., \& Thornton, C. A. (1994). Beliefs about mathematics teaching held by pre-service teachers involved in a first grade mentorship program. Mathematics Education Research Journal, 6(1), 37-55. https://doi.org/10.1007/BF03217261

Xenofontos, C. (2018). Greek-Cypriot elementary teachers epistemological beliefs about. Teaching and Teacher Education, 70, 47-57. https://doi.org/10.1016/j.tate.2017.11.007

Yang, X., Kaiser, G., König, J., \& Blömeke, S. (2020). Relationship between pre - service mathematics teachers' knowledge, beliefs and instructional practices in China. ZDM, 52(2), 281-294. https://doi.org/10.1007/s11858-020-01145-x

Yuli, T., Siswono, E., Wachidul, A., \& Hartono, S. (2019). Examining Teacher Mathematicsrelated Beliefs and Problem-solving Knowledge for Teaching: Evidence from Indonesian Primary and Secondary Teachers. 11(5), 493-506. https://doi.org/10.26822/iejee.2019553346 